\title{
Da Minima Moralia de Paulo Freire
}

\section{Resumo}

Este ensaio é uma aproximação ao Pensamento de Paulo Freire tendo como elementos fundamentais a sua concepção de Homem, de Mundo e de Sociedade. Desdobrando e articulando tais elementos, vamos em busca daquilo que constitui a base de onde emerge todo o projeto pedagógico freiriano que visa a metamorfose do Homem, do Mundo humano e da Sociedade em termos de Libertação ou do Ser-Mais. Pretendemos pôr à luz a Minima Moralia da obra de Paulo Freire de onde brota a esperança de concretização do que ele chama de o "inédito viável" - em última instância, a Libertação -, nas subjetividades, nas múltiplas relações, na história em geral.

Palavras-chave: Paulo Freire. Pedagogia. Antropologia. Ser-Mais. Ética.

\section{Para citar este artigo:}

BONAMIGO, Gilmar Francisco. Da Minima Moralia de Paulo Freire. Revista Linhas. Florianópolis, v. 19, n. 39, p. 243-270, jan./abr. 2018.

\section{Gilmar Francisco Bonamigo} Universidade Federal do Espírito Santo - UFES - Espírito Santo Brasil professorbonamigo@gmail.com 


\title{
About the Minima Moralia of Paulo Freire
}

\begin{abstract}
This essay approaches the thought of Paulo Freire, having as fundamental elements his conception of Man, World and Society. By unfolding and articulating these elements, we search for what constitutes the base from which the whole Freirean pedagogic project arises, aiming towards the metamorphosis of Men, of the human World and of Society, and which would mean Liberation or Being More. We intend to bring to light the Minima Moralia of Paulo Freire's work, from where emerges the hope of substantiating what he called the "viable unprecedented" - ultimately, the Liberation -in subjectivities, in manifold relationships, in history in general.
\end{abstract}

Keywords: Paulo Freire. Pedagogy. Anthropology. Being-More. Ethics. 


\section{Introdução}

Nós vivemos um tempo, como diz Boaventura, de "transição paradigmática”, mais epistemológica do que societal (SANTOS, 2007), talvez bem mais moderno, talvez pósmoderno, somos filhos da "arte de reduzir as cabeças" (DUFOUR, 2005). Não é à toa: vivemos o frenesi das "novidades inéditas" e da descartabilidade. Uma produção sem precedentes de bens de consumo, numa velocidade estonteante, na qual quase se fundem e se confundem ciência e tecnologia, numa lógica em que intrinsecamente se articulam e mesmo se identificam o "bom" e a "novidade"; por outro lado, um consumo sempre atrasado do "novo" que carrega o "poder de ser descartável" de toda produtividade a ser consumida. Rapidamente precisamos esquecer as coisas porque já são mais que passadas, são ultra-passadas, são feitas para durar pouco e sem reposição. Numa sociedade do consumo atrasado, o tempo humano é de uma perna só, pois o próprio presente inexiste porquanto seu movimento é assimilado pelo futuro; quanto ao passado, é bem passado, no sentido de que não faz sentido nem mesmo reter na memória o que de per se é ultra-passado. ${ }^{1}$

Nós devemos esquecer as coisas, nós devemos esquecer as pessoas, nós devemos esquecer as obras, nós devemos esquecer nossas costas, nós devemos esquecer nossa história pessoal e comum. Devemos esquecer a memória e nos esquecer da memória; nossa identidade é todo dia inédita, in-existente; se há problemas, sua resolubilidade é focal, por um jeito inédito, por um medicamento inédito, por um subterfúgio inédito. Paradoxalmente, tudo é relativo, relativo ao inédito. Será isso o pós-moderno?

Estamos imersos na avalanche mundial da materialidade e pomos em risco a “memória do humano e do desumano". Do humano vivido e do desumano evitável, se alguém ainda quer - de fato e deveras, e não apenas como uma ideia mais uma vez pretensamente inédita - viver o mais amplamente possível o humano. Parece uma significação apenas simbólico-metafórica, mas, na verdade, o sentido é literal: nós estamos num tempo de vida em que "temos dificuldade de voltar para casa" e de parafraseando Husserl - "voltar às coisas mesmas".

\footnotetext{
${ }^{1}$ Ver a esse respeito a aguda obra de Paul Ricoeur, A Memória, a História, o Esquecimento. Campinas, SP: Editora da Unicamp, 2007.
} 
Se tudo fosse relativo, não experimentaríamos "o temor e o tremor"² da distensão no presente, no passado e para o futuro de um fenômeno que se renova ineditamente e se dilata ao tempo e que tem o nome ariscoso de "violência". Inovamos nas proteções de nossas casas - talvez pertença ao passado sua pretensão de serem lares -, de nossos bens, de nossos corpos; é preciso fazer seguro da própria vida. Estamos num círculo vicioso do medo ${ }^{3}$ e, talvez, do medo apenas de morrer.

São milhões os que sofrem dessa violência velada, um tanto psicológica, mas sempre real. Muitos milhões a mais são os que sofrem da violência aberta, violência da miséria que esfarrapa e dilacera tudo num ser humano, condenados de nascimento à morte. Vergonha de uma humanidade de gênero que mata milhões e bilhões de homens no singular! ${ }^{4}$

A prisão do inédito não é causa de nada, não é a causa da violência; ela é um fato e, por mais que se camuflem as suas razões em nossas mentes, ela é tão histórica quanto a violência possível e temível. A prisão do inédito - reduzido aos bens materiais de consumo - faz parte de uma lógica maior e bem velha que só com a história se pode desvelar. Na esteira de tantos outros - Marx, Fromm, só a título de exemplo -, Paulo Freire (1992, p. 12), por um lado, denuncia em toda a sua vasta obra a "malvadeza" dessa lógica e, por outro, avança a abertura de possibilidades de viver humanamente com os outros no mundo segundo outra lógica. Para Freire, a lógica do Ter como telos de si mesma - em que o capitalismo em suas variáveis históricas é apenas o "melhor" modo de produção do Ter - em si mesma exige a violência e inaugurou na história uma sociedade de classes em que a opressão é a violência cristalizada e ideologicamente legalizada. Para Paulo Freire, a diminuição e a supressão da violência, da opressão, segue outra lógica, a lógica do Ser, a lógica do Ser-Mais. A instituição desta lógica passa pelo longo caminho da "formação do homem", a começar dos milhões de homens oprimidos, para os quais foi proibido o direito humano de "dizer a sua palavra".

\footnotetext{
${ }^{2}$ Expressão cunhada por Kierkegaard e que dá o título a uma de suas obras fundamentais.

${ }^{3}$ Ver BAUMAN, Z. Confiança e Medo na Cidade. Rio de Janeiro: Zahar, 2009.

${ }^{4}$ Ver o site oficial do Banco Mundial: 3 bilhões e 800 milhões de existentes humanos com renda diária abaixo de 2 dólares, dentre os quais 1 bilhão e 200 milhões abaixo de 1 dólar/dia. E ainda, ver o site oficial do ACNUR/ONU: em 2012, eram mais de 36 milhões de refugiados. Um ano depois, o número havia subido para 51,2 milhões.
} 
$\mathrm{Na}$ segunda metade do século passado, tempo das discussões pedagógicas infindas no Brasil, talvez se tenha dado ênfase desproporcional à novidade de outro tipo que foi o "método de Paulo Freire". ${ }^{5}$ Certamente, há na estruturação do método uma fecundidade educativa ímpar. Mas, relendo a obra de Freire, é fácil perceber que o que está primeiramente em questão não é o método, mas uma preocupação antropológica funda, a preocupação com o humano, com o humano que não advém por conta do tipo de sociedade e de mundo realizados historicamente a partir da inconclusão ontológica do homem. A lógica ontológica do homem é o Ser-Mais, o que implica, de saída, uma mexida geral na constelação dos valores e, portanto, uma Ética. A lógica do Ser-Mais põe em exercício uma Minima Moralia ${ }^{6}$ que acompanha o desdobrar-se do método educativo. E o método educativo não é de instrução; é um método de formação humana, no sentido de fazer reemergir as subjetividades oprimidas na existência delas mesmas numa tessitura de Libertação para fora (socialmente) e para dentro (na singularidade de cada Um), processo sempre intersubjetivo mediado pelo mundo.

Visitar, visitar alguém é hoje um hábito do passado. Vamos aqui re-visitar Paulo Freire em sua obra: isto é ultra-passado. Vamos visitar para não deixar esquecer, dado que as discussões pedagógicas dos primeiros anos deste século promovem um célere esquecimento da vida e da obra desse brasileiro que, arraigado em seu tempo, soube viver bem à frente dele, talvez porque - parafraseando Nietzsche - "muitas pessoas nascem póstumas". Mesmo que, depois da morte de Paulo Freire, tenham ocorrido mudanças rápidas no cenário mundial em termos econômicos e políticos - muitos autores chamaram a isto de "globalização" - com a consequente acentuação da perda de poder por parte dos Estados-Nação frente à economia transnacional; mesmo que, depois de Freire, os índices de depressão e suicídios - entre ricos, entre pobres - tenham aumentado assustadoramente como "males de civilização"; mesmo que, depois de Freire, tenha ocorrido um esvaziamento das forças emancipatórias que ebuliam desde os potes marxistas, e os problemas sociais ultrapassem os problemas da luta de classes; com

\footnotetext{
${ }^{5}$ Paulo Freire explicita as etapas e o processo de ação de seu método em diferentes obras; mas nossa opinião é de que a maneira mais simples de entendê-lo encontra-se já na Pedagogia do Oprimido, no capítulo III.

${ }^{6}$ Mínima Moralia é uma expressão tomada por empréstimo do título de uma das obras de Theodor Adorno, da Primeira Escola de Frankfurt.
} 
tudo isto, a opressão continua bem aí, ampliada e, talvez, só tenha mudado o seu jeito de acontecer.

Talvez as análises de Freire já não peguem esse "fenomenismo inédito" e exuberante de violência das beiradas da vida em comum; mas, auscultamos que a obra e a vida de Freire continuam pegando as condições de possibilidade desse fenomenismo e continuam a alavancar elementos importantes - pelo menos alguns - que poderiam e podem abrir humanas alternativas aos homens e mulheres no mundo do nosso tempo. Com efeito, serão "leis boas" infligidas aos oprimidos da Terra que, sob digestão forçada, Ihes trarão a libertação de todas as espécies de fome que, tecnicamente, já poderiam ser saciadas? Numa simples pronúncia positiva que dá o que pensar: o que pode produzir ainda hoje uma verdadeira libertação e o que pode fazê-la durar?

Eis, pois, que há muito de atual e fundo em Freire que precisa ser visitado. Visitar é uma maneira de não deixar as pessoas apenas morarem na história, mas de fazê-las habitar a vida aqui e agora. Em nossa visita a Paulo Freire, não vamos nos prender às influências teóricas, correntes ou pensadores que incidiram sobre sua obra porquanto há um sem número de teses, dissertações e artigos nos quais se efetiva essa arqueologia. Nossa pretensão é de um olhar, olhar a articulação entre o mundo, o homem e a sociedade feita por Freire a partir dos valores inscritos no horizonte de sua obra e encarnados em sua própria vida. Para tanto, nos guiaremos, sobretudo, pelo norte de três obras: Pedagogia do Oprimido, Pedagogia da Esperança e À Sombra desta Mangueira. Num primeiro momento, ouviremos o autor em suas teses fundamentais e na sua fundamentação e, num segundo momento, conversaremos com ele em sua obra.

\section{Da incursão no pensamento}

Freire não pensa ideias, pensa a existência:

Não posso entender os homens e as mulheres, a não ser mais do que simplesmente vivendo, histórica, cultural e socialmente existindo, como seres fazedores de seu "caminho" que, ao fazê-lo, se expõem ou se entregam ao "caminho" que estão fazendo e que assim os refaz também. (FREIRE, 1992, p. 97) 
Com efeito, em sociedades cuja dinâmica estrutural conduz à dominação das consciências, a pedagogia dominante é a pedagogia das classes dominantes. Os métodos de opressão não podem, contraditoriamente, servir à libertação do oprimido. Nessas sociedades, governadas pelos interesses de grupos, classes e nações dominantes, a “educação como prática da liberdade” postula, necessariamente uma pedagogia do oprimido. Não pedagogia para ele, mas dele. Os caminhos da libertação são os do oprimido que se liberta: ele não é coisa que se resgata, é sujeito que deve se autoconfigurar responsavelmente. Uma cultura tecida com a trama da dominação, por mais generosos que sejam os propósitos de seus educadores, é barreira cerrada às possibilidades educacionais dos que se situam na ambiguidade da condição humana, complica-se nas contradições da aventura histórica, tenta explicar-se na contínua recriação de um mundo que, a um só tempo, obstaculiza e provoca o esforço de superação libertadora, da consciência humana. A antropologia acaba por exigir e comandar uma política: "minha opção por aquele mundo menos malvado" (FREIRE, 1992, p. 68).

Em Freire há uma excedência humana, humanista, que serve de telos para o método que se realiza na pedagogia; esta interconexão manifesta o processo histórico em que o homem se reconhece e a conscientização não acontece apenas como conhecimento e reconhecimento, mas como adesão, opção, decisão e compromisso.

O homem, os homens encontram-se num mundo comum; em primeira mão, o que é comum no mundo dos oprimidos é a dominação, a opressão; é da coincidência de intenções que objetivam o mundo que surge a comunicação, o diálogo, a reciprocidade das consciências, donde emerge a re-criação de um mundo e a possibilidade da libertação. O mundo é o lugar do encontro de cada um consigo mesmo e com os demais homens; ele é o horizonte das significações - distorcidas e alienantes, bem como das possibilidades de libertação. Na re-criação do mundo, de suas significações pela práxis, o homem, os homens e as mulheres vão se re-descobrindo sujeitos - de si mesmos e do projeto comum. $\mathrm{O}$ homem constitui a si mesmo na comunhão humana e instaura $\mathrm{o}$ mundo em que se humaniza ao humanizar o mundo.

Para o autor, é com a palavra, ao aprender a dizer sua palavra, que o homem se faz homem e assume conscientemente sua condição humana. E eis a fortaleza de Freire: o 
método que propicia ao homem a aprendizagem de dizer a sua palavra, de pronunciar o mundo, comensura-se ao homem todo e funda toda a pedagogia. Assim,

A educação reproduz, assim, em seu plano próprio, a estrutura dinâmica e o movimento dialético do processo histórico de produção do homem. Para o homem, produzir-se é conquistar-se, conquistar sua forma humana. A pedagogia é antropologia. (FREIRE, 1978, p. 12, grifo nosso)

Decisiva aqui é a noção de consciência: ela é a capacidade do homem de distanciarse das coisas, do mundo e de projetar intencionalmente formas humanas de ser no mundo; a objetividade dos objetos é constituída na intencionalidade da consciência; o mundo, primeiramente como obstáculo, é também espetáculo, interrogação e convocação. O mundo vivido, com suas contradições, pode emergir à consciência e ser problematizado, descodificado, re-significado pela consciência capaz de o intencionar. A “hominização" não é adaptação, o homem não se naturaliza, ele humaniza o mundo; ela não é só processo biológico, mas também história. A consciência do mundo e a consciência de si crescem juntas e em razão direta: uma é a luz interior da outra, uma comprometida com a outra. Mas ninguém se conscientiza separadamente, no isolamento ou no monólogo, como - no dizer de Leibniz - mônadas, sem portas nem janelas. A intersubjetivação das consciências é tão original quanto sua mundaneidade, como um "parentesco ontológico" de cada homem no Ser. O diálogo historiciza a intersubjetividade. Numa palavra articulada: a consciência do mundo busca-se a si mesma num mundo que é comum. Se isto o é para toda consciência, então a consciência é sempre também intersubjetiva.

Se o mundo das consciências é o mundo das consciências intersubjetivas, a elaboração desse mundo é feita em co-laboração. Daí, o auto-reconhecimento só acontece se junto se der o reconhecimento do outro homem. As consciências dialeticamente promovem-se em reciprocidade; isto faz aparecer a intersubjetividade como a tessitura última do processo histórico de humanização. Daí também que a antropologia se realiza na e como práxis das liberdades em co-realização. Com isto, o método e toda a pedagogia não são processos de ensino, mas eminentemente de aprendizagem: são processos históricos, nunca terminantemente concluídos, de aprender, 
particularmente e em comum, a ser homem, a se humanizar. Aprender a dizer a palavra isto é, a significar o mundo, a si mesmo e a relação com os outros, tendo como telos imanente, intrínseco, a humanização de si e do mundo com os outros homens - é, novamente, toda a pedagogia e também toda a antropologia. E como o homem aprende a dizer a sua palavra, ele aprende a apreender a significação do mundo, a distanciar-se criticamente do que lhe é dado para fazer emergir a cultura e a história como construção temporal em que o humano se faz e se diz. Aí aparece, de maneira indeclinável, a tarefa da liberdade e da responsabilidade inscrita no realismo do movimento de existir humanamente com os outros no mundo.

Conforme o latejo da visão de Freire, no mundo dos homens, como ele vai, historicamente foi estruturado - por obra dos próprios homens - um regime que concretiza e expressa a dominância temporal acerca do "dizer a palavra". Concretamente, os homens vivem em sociedade, numa sociedade cuja significação estruturada é o regime da dominação das consciências, no qual os que mais trabalham menos podem dizer a sua palavra e no qual multidões imensas não possuem nem a condição de trabalhar. A sociedade é sociedade de classes: os dominadores mantêm o monopólio da palavra, com que mistificam, massificam e dominam; os dominados, cujo dia a dia é a opressão vivida existencialmente por todos os lados - inclusive no lado de dentro, como introjeção - sem direito à palavra, a dizer o mundo. Retomar a palavra e aprender a pronunciar o mundo é a tarefa existencial intransferível da pedagogia do oprimido, feita como vida pelos oprimidos. Neste sentido, “qualquer que seja a qualidade da prática educativa, autoritária ou democrática, ela é sempre diretiva" (FREIRE, 1992, p. 79).

O mundo, ao olhar de Freire, com sua sociedade de opressão, é habitado por uma "multidão de esfarrapados"; mas há aqueles que se descobrem nos esfarrapados: os esfarrapados, eles mesmos como esfarrapados que começam a pronunciar sua palavra sobre a vida no mundo e aqueles que se descobrem sofrendo por eles pela afronta que a existência dos esfarrapados provoca em suas existências não-esfarrapadas, obrigando a uma nova palavra sobre o mundo. É a eles todos que Freire dedicou a sua Pedagogia do Oprimido. A tomada de consciência - e aí o lugar da conscientização no método de Freire 
- abre o caminho à expressão das insatisfações sociais; tais insatisfações vão progressivamente tornando mais clara a situação local e geral da opressão. ${ }^{7}$

Isto implica em reconhecer a desumanização como viabilidade, como possibilidade ontológica, mas também - e, talvez, sobretudo - como realidade histórica. Implica em mais: a pergunta sobre a outra viabilidade, a possibilidade da humanização do homem. As duas possibilidades - a negativa e a positiva - inscrevem-se num traço constitutivo do homem: o homem é, ontologicamente, um ser inconcluso. Isto significa: o homem, por assim dizer, é habitado por uma "abertura", por uma não-predeterminação acerca de sua realização temporal. A história, a cultura são entretecidas e realizadas a partir dessa abertura como sua condição de possibilidade. Viver no mundo como homem é dar conta dessa inconclusão aberta, cuja realização no tempo é aberta e, como tal, sempre retomável e re-significável. Isto significa que, mesmo que a dominância concreta da maneira como se estruturou no tempo a formação social seja ao modo da opressão geral, tal situação não é unívoca e muito menos definitiva. É, pois, sobre este pressuposto antropo-ontológico que se fundam todo o esforço e a palavra de Freire.

A argumentação de Freire é bem simples - como sempre e, sempre, profunda para fundamentar e tomar partido a favor da viabilidade da humanização. Com efeito, a desumanização se verifica tanto naqueles que têm sua humanidade roubada pela opressão que os abate quanto naqueles que executam a opressão. Nos dois casos, tratase da distorção da "vocação do ser-mais". Isto é fundamentado assim: "se admitíssemos que a des-humanização é vocação histórica dos homens, nada mais teríamos que fazer, a não ser adotar uma atitude cínica ou de total desespero" (FREIRE, 1978, p. 30). Ao contrário, a luta pela humanização é a vocação ao Ser-Mais, ao trabalho livre, à desalienação, à afirmação dos homens como pessoas, como seres para si. A desumanização que reina, dada a abertura humana, não é um destino dado, mas o resultado de uma ordem injusta feita que gera a violência dos opressores e diz do sermenos historicamente feito, inscrito e veladamente não dito.

A violência dos opressores não instaura uma outra vocação; ela simplesmente distorce aquela de Ser-Mais, pois impede que a maioria se humanize e mesmo que os

\footnotetext{
${ }^{7}$ A nota de rodapé à página 29 da Pedagogia do Oprimido é altamente ilustrativa quanto à emergência das insatisfações oriundas dos movimentos sociais reivindicatórios.
} 
opressores humanizem-se a si próprios. Se isto fosse elevado a nível geral, cairíamos numa espécie de redução ao absurdo em que, no limite, todos precisariam abdicar de suas existências; se o opressor se nutre do oprimido e se os oprimidos abdicassem de suas existências, então a sociedade de opressão destruir-se-ia por si mesma, demolindo a própria vocação de ser-menos. Além do mais, um olhar simplesmente atento à história humana encontra múltiplos exemplos de gritos e de tentativas de libertação como expressão de um humano que não quer nem se deixa morrer de vez. E se ainda levantamos - parafraseando Heidegger - "os possíveis mais próprios de um mundo que gostaríamos de habitar", é porque o Ser-Mais é a vocação onto-histórica dos homens. Se há desalento, incremento da miséria e nutrição da morte é preciso buscar na historicidade humana a causalidade de seu advento; segundo Freire, encontraremos na ordem social injusta estruturada - e não dada como destino - a fonte geradora da violência. Certamente os opressores opor-se-ão tenaz e vivamente a qualquer tentativa de mudança, como nos mostra a própria história; por isso, a libertação, a busca real de SerMais, só pode ser uma tarefa dos oprimidos.

Há um diferencial decisivo na obra de Freire no que tange à libertação. Com efeito, se a tarefa da libertação, de hominização e humanização só pode advir dos oprimidos, essa tarefa não se conclui ou não se esgota nos benefícios da mesma libertação aos oprimidos. A tarefa de libertação dos oprimidos implica também na libertação do opressor no qual há como que, também, um déficit de humanização: o gozo que possa ter é sempre temeroso e se nutre da violência usurpadora sobre a maioria. Tal libertação implica não numa inversão de poder, do poder de oprimir; ela implica em desalojar o opressor social que violenta o humano na maioria dos homens a partir das estruturas sociais injustas, implica em desalojar o opressor que vive como hóspede no oprimido e ainda em vigiar o opressor desalojado para que não venha a se re-introduzir nas relações inter-humanas como opressor. Daí todo o trabalho complexo, desafiante e continuado de uma pedagogia libertadora, com todos os medos - inclusive da liberdade -, vicissitudes e ambiguidades que é preciso processualmente vencer.

De uma maneira mais didática, digamos com Freire como a classe opressora que constitui a sociedade exerce seu domínio e mantém a opressão. Com efeito, uma vez que a sociedade se estrutura em classes e uma domina a outra, está inaugurada e deflagrada a 
violência. Não haveria oprimidos se não houvesse uma relação de violência que conforma os oprimidos como violentados numa situação real de opressão. Os que oprimem é que inauguram e perpetuam a violência, o desamor, o terror, a tirania, a negação da maioria dos homens, a distorção da realidade e de suas causas, a mistificação ideológica das consciências, a desqualificação humana dos saberes dos oprimidos, a proibição real de ser, a coisificação dos homens.

A violência inaugurada, estruturada e exercida é um processo que passa de geração a geração de opressores e vai se constituindo numa espécie de clima geral da sociedade. Processualmente, forja-se na consciência dos opressores uma mentalidade psicológica fortemente possessiva acerca do mundo e dos homens, segundo a qual tudo pode ser transformado e reduzido ao seu poder de compra; o dinheiro passa a ser "a medida de todas as coisas" (paráfrase a Protágoras) e o lucro o “objetivo principal” (paráfrase a Marx), num reducionismo à materialidade. O caminho do Ter, assim, impede o caminho de Ser (FREIRE, 1978, p. 49). Por outro lado, se ter é condição para ser, então “esta é uma condição necessária a todos os homens" (FREIRE, 1978, na mesma página). Numa situação social em que a classe dominadora reivindica para si a exclusividade do ter, põe-se sempre a necessidade do controle sobre os que não devem ter, como exercício de um domínio que busca ser o mais completo, como se as pessoas pudessem ser reduzidas a algo inanimado. Uma das maneiras contundentes de exercício do domínio e do controle é o desenvolvimento e a apropriação da ciência e da tecnologia, por onde se cristaliza um dizer e um fazer pré-conceituosos que falsificam e mistificam as consciências e as existências dos oprimidos; isto conduz à inércia pessoal e social e ao fatalismo. Como diz Freire, "de tanto ouvirem de si mesmos que são incapazes, que não sabem nada, que não podem saber, que são enfermos e indolentes [...] terminam por se convencer de sua "incapacidade”" (FREIRE, 1978, p. 54). É o problema grave da "autodesvalia” e das manifestações "necrófilas". 8

O processo de libertação dos oprimidos, por tudo isto, "começa" com o "voltar a dizer sua palavra"; e para que a palavra venha a ser dita é necessária a experienciação de uma nova forma de diálogo; mas o diálogo não se esgota em si, pois que ele é o medium -

\footnotetext{
${ }^{8}$ Expressão utilizada por Eric Fromm e altamente heurística para Paulo Freire na compreensão da manutenção da opressão na classe oprimida. Ver Pedagogia do Oprimido, p. 56.
} 
não apenas mediação - da emergência das significações da vida, das existências oprimidas. Daí a importância, para Freire, dos “conteúdos do diálogo". Eles vão exigir o advento simultâneo e duradouro da reflexão, que vai abrindo o véu - e às vezes os muros - que se interpõe como barreira à libertação. A reflexão em diálogo sobre os conteúdos das situações concretas abre a possibilidade, já de início, de um ensaio de dizer de novo, de pronunciar a própria palavra significante e provoca uma nova tipologia de ação enquanto cada participante pertence ao mesmo mundo, visto porém de "outro lugar". Quem aprende a dizer se conscientiza e a conscientização junto com os outros em diálogo sobre os conteúdos de suas existências vai implicar em "responder por", em ser responsável, isto é, que a libertação apareça como tarefa solidária e conjunta e não como dádiva correlata à opressão. No dizer de Freire, “É como homens que os oprimidos têm de lutar e não como coisas [...] Não há outro caminho" (FREIRE, 1978, p. 60). E este caminho é trilhado num certo percurso de Educação. Como atualiza Freire na Pedagogia da Esperança: “[...] as relações entre as classes são um fato político que gera um saber de classe, que demanda uma lucidez indispensável no momento da escolha das melhores táticas a serem usadas [...]" (FREIRE, 1992, p. 93).

Os homens são estes seres de busca com a vocação ontológica de humanizar-se, cujo devir implica na criação e re-criação do mundo e das relações, a começar do próprio corpo como "corpos conscientes" e da "emersão das consciências" (FREIRE, 1978, p. 71 e 80), desdobrando-se em "inserção crítica". O movimento de ser vai sendo tecido sob a inconclusão ontológica e sob a percepção de que a realidade se dá como história e não como destino. Sendo histórica, toda circunstância - e, sobretudo, a circunstância geral de opressão - pode ser modificada, pode ser superada. E por isso, diz Freire: "aí se encontram as raízes da educação mesma, como manifestação exclusivamente humana. Isto é, na inconclusão dos homens e na consciência que dela têm. Daí que seja a educação um 'que-fazer permanente"” (FREIRE, 1978, p. 83).

Como seres inconclusos e históricos, os homens são seres mais além de si mesmos, são projetos de ser, são seres voltados para o futuro. Mas o desdobramento do futuro como "lugar de Ser-Mais" implica na consciência do presente como "lugar do aqui e agora" onde já se abre e se põe para viver o acontecimento de ser, da "ampliação do presente". Tal consciência implica, por sua vez, em voltar-se para o passado como "lugar 
da facticidade" onde moram as raízes temporais e as condições de possibilidade tanto da opressão quanto de sua superação. Por ali passa, para cada oprimido, o processo de ser "sujeito de seu próprio movimento", movimento que não pode ser isolado ou individualista, sob pena de desumanização, de uma repetição às avessas da opressão vivida, de uma contraditória "libertação egoísta”. A partir daí, o mundo volta a ser o mediatizador dos sujeitos que, em processo de educação problematizadora, incidem sobre o mundo pela ação transformadora e fazem advir sua humanização.

Disto decorre, como em espiral, que "existir humanamente é pronunciar o mundo, é modificá-lo" (FREIRE, 1978, p. 92). E eis, dialeticamente, nova presença, um novo acontecer do diálogo. O diálogo é encontro de homens, é pronúncia, é trabalho, é práxis. Freire desconfia do silêncio (FREIRE, 1978, p. 92$)^{9}$ que muitos buscam em isolamento sem levar para o silêncio a reflexividade dos conteúdos molhados de realidade. Silêncio humanamente fecundo é aquele que ele vive "à sombra da mangueira", como veremos adiante. O diálogo é o caminho pelo qual os homens ganham significação enquanto homens e, como tal, o diálogo é uma "exigência existencial”; e se é uma exigência e não um acessório da existência, o homem é dia-logos. O sentido, a razão-de-ser, a humanização emergem no encontro dos homens, no encontro em diálogo cujos desdobramentos só são determináveis no acontecer do diálogo aberto e mantido aberto, porque é aberta e inconclusa a vida e as decisões históricas sempre retomáveis, corrigíveis, dilatáveis.

Para Freire, o diálogo verdadeiro entre os homens, aquele que os põe na rota da libertação, possui suas condições constitutivas. A primeira delas é o amor profundo pelos homens e pelo mundo. Com efeito, "Não é possível a pronúncia do mundo, que é um ato de criação re-recriação, se não há amor que a infunda" (FREIRE, 1978, p. 94). Tal amor como exigência mostra a impossibilidade de um diálogo humanizante entre as classes; o amor implica em compromisso com os homens; a opressão da classe dominadora implica em violência, em inibição radical do diálogo.

A segunda condição é a seguinte: não há diálogo sem humildade (FREIRE, 1995, p. $86)^{10}$. A imposição, a arrogância, a auto-suficiência inviabilizam a comunicação, fazem as

\footnotetext{
${ }^{9}$ Na nota de rodapé.

${ }^{10}$ Ver também em Pedagogia do Oprimido, p. 94.
} 
pessoas envolvidas entrarem em defesa ou caírem no silenciamento. A força da palavra não pode estar na altura do tom, mas no poder de promover consciência e coesão pelo conteúdo e pela claridade que introduz nas existências. Um bom argumento posto de modo errôneo emperra a emersão das subjetividades.

Em seguida, temos a condição da intensa fé nos homens, em seu poder de fazer e refazer, de saber e de inventar formas de viver expressivas do Ser-Mais. Para Freire (1978, p. 95), "a fé nos homens é um dado a priori do diálogo". É a fé nos homens que alicerça a esperança na possibilidade de desalienação, de libertação; ela inscreve também no diálogo - como palavra e ação - a confiança que faz aparecer as reais intenções dos sujeitos; e o testemunho continuado, por sua vez - no qual aparecem as intenções reforça e aumenta a confiança recíproca calcada na fé nos homens.

Por fim, a outra condição constitutiva do diálogo, segundo Freire, é o pensar verdadeiro, o pensar crítico. Este pensar - como verbo de ação e não um substantivo tem como meta a transformação permanente da realidade para a continuada humanização dos homens. Este horizonte do verdadeiro dá o telos permanente e o tom da educação, em que o conteúdo do diálogo é o conteúdo mesmo da educação. Muitos projetos educativos falham porque há um erro de partida: não foram levados em conta “os homens em situação", como o conteúdo verdadeiro do diálogo. Dizendo com Freire (1978, p. 101):

O que temos de fazer, na verdade, é propor ao povo, através de certas contradições básicas, sua situação existencial, concreta, presente, como problema que, por sua vez, o desafia e, assim, lhe exige resposta, não só no nível intelectual, mas no nível da ação.

É dali que emergem os "temas geradores" do processo educativo; se há subjetividades a emergir, tal emersão deve se dar desde o início pela emersão dos temas que vão gerar o conhecimento, a consciência acerca da vida e a ação que transforma a vida. Os temas existem nos homens. E é nos homens, em suas situações de existência, pessoal e em conjunto, que é preciso que aconteça “o inédito viável” (FREIRE, 1978, p. 110). 
O “inédito viável”, a face nova de uma sociedade humana, põe-se como exigência antropológica desdobrada no esforço dos oprimidos por Ser e atualizada nas atitudes que renovam o desejo de existir. A concreção de tal esforço e de tal desejo passa inelutavelmente por um processo colaborativo e conjunto - longe do individualismo que divide e enfraquece - no qual um conjunto articulado e vivenciado de valores éticos vai fazer a diferença qualitativa da metamorfose que é preciso operar na sociedade desde as estruturas. Mas a consecução e a durabilidade desta metamorfose social segue pari i passu com a metamorfose qualitativa de cada subjetividade envolvida e emergente do processo de libertação. Neste sentido - e aí está uma das fortes tônicas do pensamento de Freire - não há verdadeira revolução social sem uma verdadeira revolução antropocêntrica e antropológica, e esta não resiste nem subsiste sem uma revolução ética - moralmente optada e inscrita na existência de cada subjetividade. Trabalho humano de "solidariedade crítica", um dos eixos éticos de toda proposta de Paulo Freire, no cerne da sua Minima Moralia, da qual falaremos logo adiante.

Tudo parece tão simples e óbvio quando temos uma noção do processo. Na verdade, para Paulo Freire (1978, p. 217), “Todo o nosso esforço [...] foi falar desta coisa óbvia": opressão, solidariedade crítica vivida e mediada, libertação como criação de "[...] um mundo em que seja menos difícil amar" (FREIRE, 1978, p. 218). Amor dentro de cada homem, amor nas relações estreitas e largas entre os homens, na lucidez amadurecida: “A história não se entrega ou se curva docilmente à vontade arrogante dos voluntaristas. As transformações sociais se fazem na coincidência entre a vontade popular, a presença de uma liderança lúcida e o momento histórico propício" (FREIRE, 1992, p. 167).

\section{Da interpretação do vivido no pensamento}

A partir dessas anotações do pensamento de Paulo Freire e a partir de algumas “provocações” que elas suscitam, ensaiamos umas "segundas anotações”, agora de caráter mais hermenêutico. Paul Ricoeur falava, próximo do tempo em que Freire escrevia sua Pedagogia do Oprimido, que o fundamental na leitura de um texto, de uma obra, é a metamorfose que o "mundo do texto" opera na subjetividade que lê e compreende ou, com outras palavras, compreender um texto é pôr-se a caminho de uma 
maior compreensão de si mesmo. ${ }^{11} \mathrm{O}$ texto de Freire dificilmente deixa intacto quem o lê, quer por aquilo que diz, quer pela simplicidade com a qual diz a densidade da experienciação humana. Sua obra “dá o que pensar!” (RICOEUR, 1969, p. 32). Os autores morrem, o mundo de suas obras permanece. E se "lá onde um homem sonha, outro se levanta para interpretar" (RICOEUR, 1965, p. 27), nossas palavras pretendem ser uma atualidade, in homini, da proposição esperançosa de Paulo Freire.

É tempo de penetrar no desde onde Paulo Freire fez sua pronúncia escrita e teceu uma certa maneira de viver. Com efeito, por que alguém dedicaria sua vida pelos oprimidos? Por que alguém produziria em si mesmo uma aproximação sempre mais radical daqueles cuja humanidade é negada? Por que alguém arriscaria sua vida pelos outros, ao ponto de precisar experienciar o exílio? Eis a facticidade que pede a expressão de suas condições de possibilidade. É aqui que esperamos tocar na Minima Moralia de Paulo Freire. Minima Moralia: conteúdos como sínteses existenciais experienciados como latejo humano que arde desde dentro e move Freire para fora. Minima Moralia, aqui, é aquilo que, se não estivesse "lá" nele e latejante, Paulo Freire não seria quem foi.

A obra - especialmente as três que ouvimos acima - e a vida de Paulo Freire nos dão a pensar e interpretar pelo menos cinco princípios antropo-éticos que o animaram e o moveram. Cinco princípios, eminentemente éticos, cada um habitado e movimentado por uma lógica intrínseca, num dialético remetimento mútuo. Em primeiro lugar, e para todos os lugares e efeitos, "primeiro as pessoas, depois as coisas". Com efeito, se o homem vive com os outros no mundo como sua situação ontológica, se o mundo é constituído como mundo humano na historicidade do mesmo homem, se o homem se faz e se realiza (como ser) no tempo do mundo como tempo humano, se homem, mundo e história só o são à razão do homem mesmo, então a presença de cada homem à vida é o que efetivamente conta e deve contar. Inverter a ordem deste "acontecimento de ser" é provocar o ferimento ontológico do humano; introduzir a opressão como "lei da convivência humana", opressão pela qual grande parte dos homens são realmente impedidos de ser, é introduzir no tempo simplesmente o absurdo, em que as coisas do

\footnotetext{
11 Paul Ricoeur desenvolve amplamente esta questão em seu livro Du Texte a l'Action: essais d'herméneutique II. Paris: Seuil, 1986. Ver também de Ricoeur Interpretação e Ideologias. Rio de Janeiro: F. Alves, 1977, principalmente as páginas 45 a 60.
} 
mundo - por motivo das quais a opressão se instala - passam a valer ontologicamente mais que o próprio homem que as institui como "coisas de valor".

Certamente que há sofrimentos nos existentes humanos cuja razão se inscreve nas possibilidades e limites físico-biológicos do homem e, como tais, muitos deles não podem ser removidos - pelo menos ainda, como por exemplo, o sofrimento da perda pela morte de alguém, morte que mostra a finitude humana. Não são esses sofrimentos que ferem ou impedem o homem de ser homem, por mais breve que seja o seu tempo de vida; são os sofrimentos, as violências produzidas e cometidas contra o homem em sua realização pelo(s) homem(s): isto é o que historicamente pode e deve ser evitado. Se o homem, como vimos, é um ser inconcluso e vocacionado ao Ser-Mais, então urge reafirmar, desde dentro de Freire: "primeiro as pessoas, depois as coisas."

Em segundo lugar, "ninguém dá o que não tem". Este princípio é de uma “obviedade evidente"; mas, dadas as condições em que se inscreve nossa consciência e nosso estar no mundo em nosso tempo e, dadas as condições infra-humanas em que vive a maioria da humanidade no que se refere ao manejo das coisas, tendo em vista a satisfação do que Agnes Heller (1982, p. 17) chamou de "carecimentos radicais", a obviedade simplesmente inexiste ou assume contornos ideológicos. Os bens materiais e de cultura, nos quais se põe decisivamente - não unicamente - a mediação do trabalho, não são acessíveis, à proporção dos carecimentos, a todos os homens. Toda forma de paternalismo e "generosidade assistencial esporádica" é o falseamento de uma situação social histórica em que os que não têm nem um minimum para si são os que produzem o necessário e o excesso daqueles a quem Marx, Freire e tantos chamaram de “opressores". Neste sentido, ninguém deveria dar o que não tem; o contrário é violência. Ferir-se, exaurir-se, deixar-se morrer por não poder preencher seus próprios carecimentos radicais para que os opressores continuem como tais é a primeira injustiça, aquela cometida contra si mesmo. Esta certeza existencial, desde o exame das situações históricas, lateja na interioridade de Freire e o move a um certo tipo de ação.

Um terceiro princípio que auscultamos no pensamento e na vida de Freire é parente próximo do anterior: "ninguém doa o que não é". Dessa forma, no pensamento de Freire - principalmente na Pedagogia do Oprimido - aparece muitas vezes a afirmação acerca da 'incompetência constitutiva' do opressor quanto ao estabelecimento de uma 
justiça real. Com efeito, o que o opressor pode dar e doar aos oprimidos - e isto é feito efetivamente e de muitas maneiras - é aquilo que ele mais tem e é: opressão. Se o opressor pretendesse verdadeiramente resgatar os oprimidos como humanos, isto seria a sua própria ruína. E Freire é lúcido: os opressores não se querem arruinados. Por isto, a libertação dos oprimidos encontra o seu ponto de partida, seu processo e seu caminho nos oprimidos mesmos. De fato, se eles estiverem habitados pelo "desejo de libertação" - o que já implica o desvelamento e a certeza da opressão - é esse desejo transfigurado em projeto comum que pode doar à subjetividade e à intersubjetividade oprimidas a restituição da sua humanidade. Parafraseando Spinoza, para quem o homem se define como "esforço para existir" 12 , poderíamos, com Freire, inverter os termos: "é pelo desejo de ser que o homem se esforça por existir". Em Freire, o desejo de uma justiça real produz nele a aproximação a quem não experiencia o acontecimento real da justiça e lhe traz a certeza interior de que a justiça só pode nascer desde ali.

Em quarto lugar, o princípio "a verdade é da ordem da vida”. Certamente há uma preocupação epistemológica em Freire e seu método tem tudo a ver com isto. Não há uma atitude anti-científica; ao contrário, a ciência é, em seu pensamento, uma construção humana de imenso valor e, dependendo dos fins, possui um incrível potencial humanamente revolucionário, libertador. Mas a preocupação fundante de Freire é com a "verdade fundante", a verdade da vida, a verdade das precisões e carecimentos da vida, da pertença à vida, da habitação da vida em cada homem, com a qualidade da vida em todas as relações, com a verdade da situação vivida em cada existência, com a verdade da opressão que é a de matar a vida. Em Freire, o critério da verdade da vida chama-se humanização, o Ser-Mais, a realização da constitutividade humana que se efetiva verdadeiramente no que ele escreveu como "a prática da liberdade". Disso decorre que nenhum conhecimento encontra o seu telos em si mesmo; o conhecimento é sempre ambígua mediação, mediação que, dependendo dos fins, pode matar a vida e, dependendo de outros fins, diametralmente opostos, pode aumentar, incrementar imensamente a vida. Em Freire, o latejo da verdade constitutiva tem prioridade sobre as aventuras epistemológicas.

\footnotetext{
${ }^{12}$ Ver SPINOZA, B. Ética. São Paulo: Nova Cultural, 1988. v. II, Livro III, Proposição VII, p. 117.
} 
Por fim - e isto não significa que não haja outros, que outros olhares podem colher -, o princípio de que "a vida se vive no singular, mas a presença do outro é aí desde sempre". Este princípio encontra acolhida no pensamento de Kierkegaard, no "cavaleiro da fé", mas a maneira de vivê-lo é pouco kierkegaardiana. De fato, em Freire, a compreensão do homem pelo isolamento do homem de sua comunidade só pode ser feita mediante um ato a-histórico e irreal de abstração. Os homens e mulheres procedem dos homens e mulheres; a construção de uma cultura e sua permanência é sempre comunitária; a transformação do mundo e sua significação temporal são historicamente processos comunitários; os homens singulares morrem e a humanidade é ainda aí, inclusive com seus mortos. Por outro lado, cada homem é único, é diferente, cada história é perpassada e entretecida com os outros, mas as sínteses existenciais são pessoais e se extravasam em sínteses de valor comunitário; a transcendência por relação às formas de vida e a busca do novo acontece nas subjetividades; é cada homem que diz sim, é cada homem que diz não, inclusive pode dizê-lo à própria comunidade; é cada homem, é cada mulher, é cada nova criança que precisa viver, deve se libertar, deve se humanizar. Numa dialética em forma de espiral, quanto mais cada existente humano se realiza, mais humana a comunidade; quanto mais humanizada a comunidade, mais provenção de identidades humanas. A articulação da dialética entre homem e comunidade é conduzida, in concreto, por uma outra dialética: da igualdade na diferença. Respeitar a unicidade de cada um e provocar a contribuição singular de cada um em prol de um projeto humano de vida em comum é um dos latejos vividos por Freire. Uma palavra de Boaventura é aqui altamente iluminadora: "Temos o direito de ser iguais sempre que a diferença nos inferioriza; temos o direito de ser diferentes sempre que a igualdade nos descaracteriza" (SANTOS, 2008, p. 313).

A partir do que foi exposto na primeira parte e da posição destes "princípios", segundo nossa breve hermenêutica, novos escavamentos se põem. Há mais que dá o que pensar. Junto aos "princípios" anotados, o pensamento de Freire nos dá a pensar que não há libertação sem solidariedade: crítica e ativa, como um eixo ético no cerne da Minima Moralia das existências em libertação. Os princípios não ganhariam vida e não se tornariam operantes sem o latejo vívido da solidariedade. A solidariedade, na vida e na obra de Freire, está por debaixo dos "princípios" como uma "máxima” que anima a 
subjetividade inteira e dá luz lógica para a maneira de encarnar os "princípios". Solidariedade, em Freire, é a exigência e, ao mesmo tempo, a proposta que pretende inaugurar o advento de uma nova forma de racionalidade para todos poderem viver no mundo - inclusive o opressor libertado ou resgatado em sua humanidade alienada às avessas. Solidariedade que implica o valor da consciência e da conscientização que dá novo lugar e novo valor ao conhecimento, solidariedade que põe as consciências emergindo no valor do diálogo, solidariedade que põe a consciência e o diálogo numa atitude operante de co-laboração orientada para um projeto comum; projeto comum de libertação que implica na suprassunção do individualismo e na capacidade de organizar mediações, tão éticas quanto o fim; projeto comum que coordena, por um lado, o resgate de formas culturais humanizantes reprimidas e, por outro, a invenção de novas sínteses culturais movidas à solidariedade. Solidariedade que nunca se completa e coordena a paz inquieta de um processo global de Ser-Mais que tem o belo nome de Libertação.

O vetor crítico da solidariedade crítica e ativa indica todo o labor da conscientização acerca da opressão recebida verticalmente e repetida nas relações horizontais entre os co-iguais em opressão, o labor da desalienação e da pronúncia - às vezes em forma de grito - do mundo. O vetor ativo da solidariedade crítica indica todo o labor das saídas conjuntas, do resgate de lógicas, saberes e fazeres abafados; lógicas redescobertas, lógicas potenciadas, lógicas re-operantes, múltiplas lógicas que inventam e renovam a solidariedade, numa "ecologia de Saberes" (SANTOS, 2007, p. 54).

O pensamento e a vida de Freire nos dá a pensar que não há libertação sem o valor fundante e vivido da benevolência. Eis que, em nosso escavamento na vida e na obra de Freire é preciso ainda descer mais, descer por debaixo da máxima da solidariedade crítica e ativa. É preciso tocar no nascedouro do elan da máxima da solidariedade e da lógica da operação dos princípios. Eis o nascedouro: a benevolência! Onde lemos em Freire gratuidade, nós escavamos a benevolência como outro "eixo" da Minima Moralia que se encarna como um "imperativo vivido": o imperativo de Ser-Bom. Com efeito, a benevolência por si e pelo outro é, em Freire, quem deve coordenar, em última instância, a forma de viver com a qual vem se dizer a identidade moral do homem. A benevolência pede consciência e decisão por ela; ela pode advir e precisa advir num processo real que 
atravessa a consciência de auto-libertação e inter-libertação criadoras realizadas na solidariedade crítica e faz os princípios virarem vida.

Freire é consciente de que, dada a inconclusão humana e a infinita gama de possibilidades de escolher e de viver em todo presente, as leis - justas - são efetivamente necessárias para um mínimo de estabilidade da vida em comum; mas Freire também tem presente que, embora necessárias, as leis são insuficientes, elas não dão conta de coordenar todos os espaços/tempos onde a vida em comum se dá e se expressa. A benevolência, no fundo, é o que faz compreender e dar o sentido das próprias leis. A lei é ao mesmo tempo fundamental e limitada: o devir cotidiano exige um surplus de humano que a lei não pode formar no homem nem cobrar do homem. As leis até certo ponto podem coibir a violência, mas não conseguem formar o homem não-violento. Neste sentido, os projetos qualitativos de vida em comum têm mais força e poder heurístico; a convivência e as exigências de efetivação dos projetos de vida em que cada um se reconhece são propulsores de novas sínteses antropológicas e morais, tanto subjetivas quanto intersubjetivas. A benevolência é que faz cuidar sem peso daqueles que já não podem trabalhar, da velhice e de sua sabedoria, da viúva, do órfão, do irremediavelmente doente; é a benevolência que introduz e mantém pelo menos um tanto bom de ternura no mundo; é a benevolência que vence a primeira indiferença pelo outro e faz com que qualquer outro - desde aquém do mérito ou dos talentos, na sua dor ou sem ela, sempre com afecção - nos seja importante. Sem benevolência não há como vir a libertação verdadeira nem como fazê-la durar. Sem benevolência há legalismo; e o legalismo é uma face da violência, de opressão oficializada.

Do ponto de vista ontológico, a lei experimenta o seu limite máximo: os homens são finitos. Uma das faces ontológicas da finitude humana é a falibilidade; a lei pressupõe a falibilidade humana, pois só um ser que pode falhar precisa de normas e leis; mas só um ser aberto ontologicamente pode vir a cumprir normas e leis. A lei trabalha com a evitabilidade da falha, mas é impotente quanto a estancar a falibilidade. É por isto que o perdão se impõe nas relações não como algo teológico ou de alguma maneira transcendente; o perdão é uma exigência relacional ontológica que só a benevolência pode coordenar o seu exercício e manter a solidariedade e o valor incondicional de cada Um para além da falha. 
Para Freire, nem mesmo no opressor podemos dizer que haja uma malevolência consciente ou pelo menos irremovível; a inconclusão humana abre sempre a possibilidade de reversão, o histórico é sempre reversível, mesmo que aquilo que se inscreve no tempo seja inapagável. Mas não basta ao opressor dizer que "não sabia” de suas violências, de sua cumplicidade trágica com a violência; é preciso, de alguma maneira contundente, libertar-se pelo envolvimento no processo maior de libertação social. Uma vez que a consciência trouxe luz à morada, há que com-prometer-se; neste sentido, põe-se a exigência de trabalhar mais numa “justiça de resgate” e evitar uma "justiça de carrasco".

O pensamento de Freire nos deu e nos dá de novo a pensar no problema do silêncio. Como já indicamos anteriormente, na Pedagogia do Oprimido, Freire "não gosta" do silêncio, do silêncio social; mas gosta do silêncio de quem leva um mundo para casa e sofre em silêncio a sua transformação. Há em Freire o silêncio necessário, para as corujas “de dia”, para os homens "de noite": ali se maturam sínteses, ali se descobrem nascentes de sentido que o "barulho" não deixa encontrar; é preciso visitar a sombra desta mangueira: uma solidão silenciosa para a reflexão geral no espaço/tempo da mangueira, onde a sombra traduz a serenidade necessária ao pensamento, à acomodação dos aprendizados. O sol vem dizer o calor da vida bem ali, logo além dos contornos indefinidos da mangueira. A sombra se movimenta conforme o sol da vida se move; na verdade é o homem e a mangueira que se movem e dão o teor de sentido no sol da vida. A sombra e a mangueira, o pensamento e o silêncio não são a morada do homem; são uma instância de passagem formativa e, como tal, uma mediação diacrônica moral para voltar aos "transformes" da vida. À sombra, por um lado, o esvaziamento das ideologias e preconceitos introjetados, a elevação dos medos vividos à consciência, a lucidez acerca da própria insensatez das atrofias humanas vividas; por outro lado, a pronúncia - que começa pelo balbuciar temerário - de uma palavra que provoca a necessidade de adentrar-se, de aderir, de conviver diferentemente com os outros no mundo. Se a práxis em colaboração com os outros é socialmente catártica, a sombra é o seu polo dialético: ela degusta e separa os sabores, insossos ou provocantes, insensatos e picantes das experiências da vida, da tessitura da vida. É à sombra da mangueira que pessoalmente acabamos de expulsar o opressor em nós e "hospedamos o outro". Eis que faz parte da Minima Moralia de Freire, a mediação diacrônica do silêncio reflexivo. 
A benevolência e a solidariedade têm suas raízes bem próximas das da mangueira. As raízes da mangueira seguram-na de pé, elas fazem a mangueira existir, elas alimentam a mangueira que dá sombra e frutos. Mas nós não vemos as raízes da mangueira e, contudo, sabemos que elas estão "lá". A benevolência é o que segura a vida humana, para além de todo ferimento historicamente inscrito. A benevolência vai buscar no silêncio novos sentidos assim como as raízes da mangueira. A benevolência faz ver que, para não perder o rosto das pessoas é preciso lembrar delas em si; ela faz ver que para rever o próprio rosto é preciso o espelho do silêncio à sombra de alguma mangueira. A benevolência incorpora o pé do tronco da solidariedade.

Assim como os peixes não procriam, nem se fecundam, nem desovam nas águas turbulentas das cachoeiras, é preciso um remanso de muitos movimentos silenciosos e invisíveis para o homem suscitar sua face humana. Mas o que seria do remanso sem as águas outras e novas que renovam as águas do remanso? Se no seu silêncio solitário o homem não levar uma multidão de outros, morre de ostracismo, de alienação, de vazio, de ferimento ontológico.

O que se vive e se gesta à sombra não é só o "fervor da luta", mas também o fruto benevolente da ternura, da sensibilidade poética e contemplativa, do sentir o pulso da vida, de auscultar o coração com instrumentos apropriados para desmanchar preconceitos e maneiras de sentir equivocadas, porquanto ainda se traduzem em alguma forma de violência, contra si, "contra o filho", contra a "nascente do rio". A benevolência faz com que cheguemos perto, faz com que venhamos bem perto do homem; tão perto que nós incluímos o homem em nós e o levamos no bonde do pensamento e do afeto para que ele nos seja sempre o próximo, nas infinitas faces da solidariedade. A benevolência pede à sombra da mangueira que ela ajude o homem a "virar as bolinhas dos olhos para dentro" para ver mais fundo o próprio movimento de ser do homem e o seu poder-ser-mais. Sombra/silêncio e benevolência/solidariedade constituem o espaço/tempo da nomia, do burilamento da autonomia, decisiva e teor de libertação. Neste espaço/tempo, re-memorar faz re-viver; e re-viver é atualizar a potência de um sentido que um dia clareou a existência. Paulo Freire só foi quem foi e fez o que fez, segundo nossa hermenêutica, se esta Minima Moralia viveu ali! Pedagogia da Minima 
Moralia aplicada a si mesmo e que "oficialmente" Paulo Freire não escreveu porque teria que falar muito de si!

\section{Conclusão}

Feito este percurso - parcial e por si mesmo inconcluso - da incursão e da interpretação de elementos decisivos da obra de Paulo Freire, retenhamos algumas sínteses abertas que simplesmente se põem. As sínteses que "selecionamos" não são colocadas numa sequência hierárquica, mas todas elas pedem umas as outras e certamente vão faltar sempre mais algumas.

Uma primeira síntese refere-se ao projeto pedagógico. Com efeito, o telos que guia e acompanha todo o processo educativo é a libertação do(s) homem(s). É um processo a ser começado alavancando mudanças na visão de mundo, de homem e de sociedade, nas subjetividades, nos valores, nas mediações. O pedagógico não é só o ensinar, nem mesmo só o formar; mas o processo de forjamento de uma "outra" humanidade, inclusive do ex-opressor. É neste sentido que a Pedagogia é toda a Antropologia. É o homem, qualquer homem, o valor incondicional. Ora, se a realidade histórica nega à maioria dos homens o seu valor incondicional, urge insurgir-se conscientemente contra ela, indignação e insurreição que começam aqui e acolá com a pronúncia do mundo.

Junto desta segue-se uma segunda: a violência - qualquer violência historicamente instituída e feita - é o que fere e mata o homem, desumaniza o homem. Uma sociedade de classes é a legalização da violência, cuja face é a injustiça. A educação, ou ela afronta a injustiça ou ela aliena e corrobora a violência.

Em terceiro lugar, Freire aposta na possibilidade - melhor, na necessidade e mesmo na exigência - de um projeto comum de humanidade em humanização. Longe de uma estrita inversão de domínio e de poder na luta de classes, a indicação é na direção de uma libertação cujo conteúdo inclua a satisfação dos carecimentos radicais de todos, satisfação que inclui a superação das "vestes esfarrapadas" e das "bocas vazias das multidões", junto com a satisfação da "fome de cultura", do "desejo do afeto", numa 
palavra, do "ser-reconhecido como homem", que é o conteúdo concreto do Ser-Mais e ao mesmo tempo o índice histórico da libertação.

Em seguida, aparece-nos que a educação, como Freire a concebe, é o locus por excelência onde se inicia, se avança e se continua o processo de Libertação. Na educação, os “temas" e conteúdos que geram a vida e a morte nas existências podem vir se dizer e sobre os quais e diante dos quais cada um precisa responder. Mas as respostas - mesmo que venham carregadas de indignação - precisam ser em si mesmas libertadoras e nãoviolentas: numa concepção diametralmente oposta ao do Príncipe de Maquiavel, os fins, em Freire, não justificam os meios; há, como vimos, uma Minima Moralia que sustenta, coordena, orienta e ao mesmo tempo se faz em todo o acontecer e devir pedagógico. Os valores vão desde a simplicidade/humildade, passando pela confiança/fé nas pessoas, pela coragem/amor no engajamento, pelo médium do diálogo, até a benevolência e a solidariedade que são quem, no fundo, dão o tom da humanização.

Mas tais valores não são impostos, são exigências que aparecem nas relações mediadas e ancoradas no diálogo. Porque é nas relações que "as coisas" têm de ser mudadas e é nas subjetividades que a humanização se vive, a Minima Moralia vivida é o aí do reconhecer e ser-reconhecido, do onde é preciso chegar, desde agora, subjetiva e intersubjetivamente. Uma Minima Moralia garante que também o opressor pode se libertar e, então, pode ser mantido vivo como homem. A educação - que começa lá na “problematização" - pode também estar penetrada de preconceitos fundados em antivalores, aqueles que podem esconder e matar a vida emergente. A educação é um lócus privilegiado de desmonte do que é anti-valor, mas que é “valor de opressão". É neste sentido que ao expulsar o opressor introjetado e hospedado em nós, é preciso expulsar também o que ele trouxe para a nossa morada e refazer, numa nova práxis, uma nova e/ou rememorada Minima Moralia.

Eis, pois, uma “pedagogia do óbvio", que é fácil de entender e, talvez, fácil de lembrar. É mais ou menos simples assim: "se há tanta comida, então todos podemos comer". Mas, "se há muita comida, se muitos estamos com fome, se não podemos trabalhar e se não podemos comer, então a conta da matemática da vida está errada". A educação - mas não simplesmente a Escola - é o caminho trilhado que pode nos levar a 
todos os tipos de comida que podem saciar nossas múltiplas fomes. Fora disso, educação é opressão.

No tempo do ineditismo consumido, da redução esquizofrênica das cabeças, do depauperamento do afeto no individualismo, de uma sociedade sem rumo humano urge pensar e não consentir que grandes "lições" de possível humanidade maior não morram com quem as escreveu e com sua vida as inscreveu nas tábuas do barco dos homens. De vez em quando as inscrições das lições voltam para dizer de novo o que já sabemos: a insuficiência de nossa "sabedoria" porque parca vai a vida. Então podemos re-ver que a bússola de Freire, com os ponteiros de sua Minima Moralia, ainda vai dar muito o que pensar; o "inédito viável” de Freire é viável desde uma certa Minima Moralia. Talvez numa simples frase de Freire espalhada em várias de suas obras e inscrita em sua vida: "Mãos de homens e de povos que se estendam menos em gestos de súplica, e se vão fazendo, cada vez mais, mãos humanas que transformem o mundo [...]" (FREIRE, 1978, p. 32, grifo nosso); talvez como um simples poema, que qualquer um pode pronunciar e que carregue, do começo ao sem fim, sempre, a instauração libertadora sempre temporal e localizada: o Reconhecimento incondicional de todos em cada Um. 


\section{Referências}

BAUMAN, Z. Confiança e medo na cidade. Rio de Janeiro: Zahar, 2009.

DUFOUR, Dany-Robert. A Arte de reduzir as cabeças. Rio de Janeiro: Companhia de Freud, 2005.

FREIRE, Paulo. Pedagogia da esperança: um reencontro com a pedagogia do oprimido. Rio de Janeiro: Paz e Terra, 1992.

FREIRE, Paulo. Pedagogia do oprimido. $5^{\text {a }}$ ed. Rio de Janeiro: Paz e Terra, 1978.

FREIRE, Paulo. À Sombra desta mangueira. Rio de Janeiro: Editora Olho d'Água, 1995.

HELLER, Agnes. Para mudar a vida. São Paulo: Brasiliense, 1982. p. 17.

RICOEUR, P. Le Conflit des intérprétations: essai d' herméneutique. Paris: Seuil, 1969.

RICOEUR, P. Du Texte a l'Action: essais d'herméneutique II. Paris: Seuil, 1986.

RICOEUR, P. De l’Interprétation: essai sur Freud. Paris: Seuil, 1965.

RICOEUR, P. Interpretação e ideologias. Rio de Janeiro: F. Alves, 1977.

RICOEUR, P. A memória, a história, o esquecimento. Campinas, SP: Editora da Unicamp, 2007.

SANTOS, Boaventura de Sousa. A crítica da razão indolente: contra o desperdício da experiência. $6^{\text {a }}$ ed. São Paulo: Cortez, $2007 a$.

SANTOS, Boaventura de Sousa. Renovar a teoria crítica e reinventar a emancipação social. São Paulo: Boitempo, 2007b.

SANTOS, Boaventura de Sousa. A gramática do tempo: para uma nova cultura política. $2^{\mathrm{a}}$ ed. São Paulo: Cortez, 2008.

SPINOZA, B. Ética. São Paulo: Nova Cultural, 1988.

Recebido em: 21/06/2016 Aprovado em: 19/09/2016

Universidade do Estado de Santa Catarina - UDESC Programa de Pós-Graduação em Educação - PPGE Revista Linhas Volume 19 - Número 39 - Ano 2018 revistalinhas@gmail.com 